\title{
Seasonal stability of snow cover in Poland in relation to the atmospheric circulation
}

\author{
Malgorzata Falarz
}

Received: 30 September 2011 / Accepted: 20 March 2012 / Published online: 12 April 2012

(C) The Author(s) 2012. This article is published with open access at Springerlink.com

\begin{abstract}
The seasonal stability of snow cover (ISS) was defined as a percentage ratio of the real and the potential snow cover duration in a winter season. Main results of the study are as follows: (1) alternately occurring periods of high and low values of the index of snow cover stability did not appeared simultaneously in mountainous and nonmountainous areas; (2) in the majority of Poland area both zonal and meridional components of the atmospheric circulation influence the ISS; however, in south the meridional air flow reveals the stronger impact, mostly due to the intensification of the southern advection by the foehn effect; and (3) changes of two or three indices describing atmospheric circulation explain up to $50 \%$ of the ISS in Poland. The diminishing stability of snow cover in Poland corresponds with an increasing intensity of the advection from the western sector in winter in the second half of the twentieth century in Europe.
\end{abstract}

\section{Introduction}

In areas where the snow cover appears and disappears many times during a winter season, a question of its stability seems to be principally important. The majority of Poland belongs to these areas. A discontinuity of seasonal snow cover is an unfavorable phenomena. A disappearance of snow during the winter season could be a cause of insufficient protection of wild and cultivated plants against the

\footnotetext{
M. Falarz $(\bowtie)$

Department of Climatology, Faculty of Earth Sciences,

University of Silesia,

41-200 Sosnowiec,

ul. Będzińska 60, Poland

e-mail: malgorzata.falarz@us.edu.pl
}

effect of low air temperature. The lack of persistence of snow cover also is the reason for insufficient conditions for winter sports and reduces the attractiveness of the health resorts in winter.

The seasonal stability of snow cover is defined here as a percentage ratio of the real and the potential snow cover duration in the whole cold period of the year (called further a "winter season"). The term was firstly used by Leśniak (1981) and was named "an index of snow cover stability" (ISS). The real duration of snow cover is the number of days with snow cover $\geq 1 \mathrm{~cm}$ in the winter season. The potential duration of snow cover was defined by Leśniak (1973) as the time (days) between the first and the last occurrence of snow cover in the winter season, i.e., between the first and the last day with weather conditions allowing the formation or occurrence of snow cover. The ISS of $100 \%$ informs that the snow cover occurred for the whole winter season without any break; the smaller is the value of the index, the longer was the period without the snow cover between the first and the last day with snow cover in the winter season.

Changes of the seasonal snow cover in the area of Poland as well as in the whole world are already quite well-known (e.g., Gutzler and Rosen 1992; Groisman et al. 1994; Walland and Simmonds 1997; Brown 2000; Dye 2002). Poland is located within the pointed zone by Brown and Mote (2009) where seasonal mean air temperatures are in the range of $-5^{\circ}$ to $+5^{\circ} \mathrm{C}$; these areas showed the largest decreases in snow cover duration during the 1966-2007 period due to their high sensitivity to climate changes (Brown and Mote 2009).

In most of Poland area, a slight decreasing trend (statistically significant only in a few measured points) was observed in the real snow cover duration and the maximum seasonal depth of snow cover during the second half of the twentieth century, but no change was distinguished for longer periods (70-100 winter seasons; Falarz 2004). A 
positive tendency of snow cover in the second half of the twentieth century was observed only in areas with abundant snow cover, i.e., northeastern Poland (as regards the depth of snow cover) and in the mountains (as regards the duration of snow cover; Falarz 2004). The potential period of snow cover showed a tendency to increase in the majority of Poland; this trend only appeared to be statistically significant at $p<0.05$ in a few meteorological stations (Falarz 2007b). The lengthening of the potential period of snow cover in Poland is mainly connected with an earlier and earlier occurrence of the first day with snow cover in autumn. The most important results of the initial investigations of the stability of snow cover are as follows: (1) the average coefficient of stability of snow cover varies in Poland area from below $40 \%$ in the west to above $60 \%$ in the northeast and above $70 \%$ in higher parts of the mountains; (2) the course of the isoline $50 \%$ of the coefficient in Poland is very close to the isotherm of January $-3^{\circ} \mathrm{C}$, which is, according to Köppen and Geiger climate classification, the border between the moderate warm and boreal climate; (3) in the second half of the twentieth century (1948/19491997/1998) the stability of snow cover indicated a slight negative trend in Poland (with the exception of the highest parts of the Sudety-mountain) of -2 to -3 percent points per 10 years, statistically significant $(0.05)$ in 7 measure points; (4) for longer periods (80 winter seasons) in southern Poland in the stability of snow cover does not appear any changes (Falarz 2010).

The snow cover variability in Poland is mostly under the impact of the macroscale circulation connected to atmospheric patterns over the Atlantic Ocean (Bednorz 2002; Falarz 2007a). A reduction the thickness of the snow cover causing the shortening of its duration in Central Europe is connected to deep, wide cyclones located in north, northwest, or west from its area (Bednorz 2009). Many papers investigated interactions between the atmospheric circulation and seasonal or decadal snow cover in different parts of the world (e.g., Clark et al. 1999; Leathers et al. 2002; Saito et al. 2004; Bao et al. 2011). However, the impact of circulation changes on the stability of the snow cover in the course of the winter season is less known. Some works studied the influence of atmospheric circulation on midwinter (Grundstein and Leathers 1998) or spring melting snow cover (Ueda et al. 2003). Some papers present models of snow cover-atmospheric boundary layer interactions (Strack et al. 2003; Rodell and Houser 2004).

The aim of the study is to investigate the atmospheric circulation influence on the seasonal snow cover stability in Poland and, as a consequence, to answer a question: what was the circulation reason for the decreasing trend of the seasonal stability of snow cover in Poland in the second half of the twentieth century? The study is the contribution to knowledge of snow cover changes in Eurasian continent.

\section{Data and methods}

Series of the ISS in Poland for 60 meteorological stations for the period 1954/1955-1997/1998 were created on the base of the seasonal real and potential snow cover duration (Fig. 1). The initial data originates from everyday snow cover observations at six UTC (Falarz 2002). A day with snow cover is a day with snow of at least $1 \mathrm{~cm}$ depth covering at least $50 \%$ of the observed area. The daily data were complete for all stations except for Sulejów. Values of the seasonal real and potential snow cover duration in this station for two winter seasons (1954/1955 and 1955/1956) were filled in by methods of regression analysis using data of Wieluń and Łódź which appeared to be strongly correlated with that station.

The initial investigations of the multi-year variability of the analyzed index (mentioned shortly in the introduction) were widen by using the principal component analysis for the area below $500 \mathrm{~m}$ above the sea level (i.e., for all stations except for Kasprowy Wierch-1,991 ma.s.1., Śnieżka-1,603 ma.s.l., and Zakopane-857 ma.s.1.). Statistical significance (at the level of 0.05 ) of snow cover stability time trends was verified.

To investigate relationships of the stability of snow cover and the atmospheric circulation two kinds of indices related to atmospheric circulation were used: (1) particular mesoscale indices (describing the atmospheric circulation directly over Poland area), i.e., (a) zonal index $\left(Z_{1}\right)$, (b) meridional index $\left(M_{1}\right)$, (c) cyclonicity index $(C)$; (2) general macroscale indices, i.e., (a) zonal index $\left(Z_{2}\right)$ calculated as a difference of the average sea level pressure between two grid points located on the meridian $20^{\circ} \mathrm{E}$ (running through the middle of Poland area): $72.5^{\circ} \mathrm{N}$ and $32.5^{\circ} \mathrm{N}$, (b) meridional index $\left(M_{2}\right)$ calculated as a difference of the average sea level pressure between two grid points located on the parallel $52.5^{\circ} \mathrm{N}$ (running through the middle of Poland area): $0^{\circ}$ and $40^{\circ}$ E. The data for sea level pressure originate from Reanalysis Project of the National Center for Atmospheric Resesarch (http://www.cdc.noaa.gov/cdc/reanalysis).

The mesoscale indices $\left(Z_{1}, M_{1}, C\right)$ were counted on the basis of types of atmospheric circulation set for each day by Osuchowska-Klein and Pawłowska for Poland area (Osuchowska-Klein 1975; Osuchowska-Klein and Pawłowska 2000). The construction of the indices basing on Niedźwiedź's method $(1998,2011)$ with some necessary modifications was described in detail by Falarz (2007a). There were counted indices $\left(Z_{1}, M_{1}\right.$, $C)$ for different winter season periods (Dec-Mar, DecFeb, Nov-Feb, Nov-Mar), then correlations between the ISS in Poland (counted for the whole cold period of the year) and those indices were examined. The strongest dependencies were found in most cases for the indices counted for Dec-Feb, so that period was selected for 


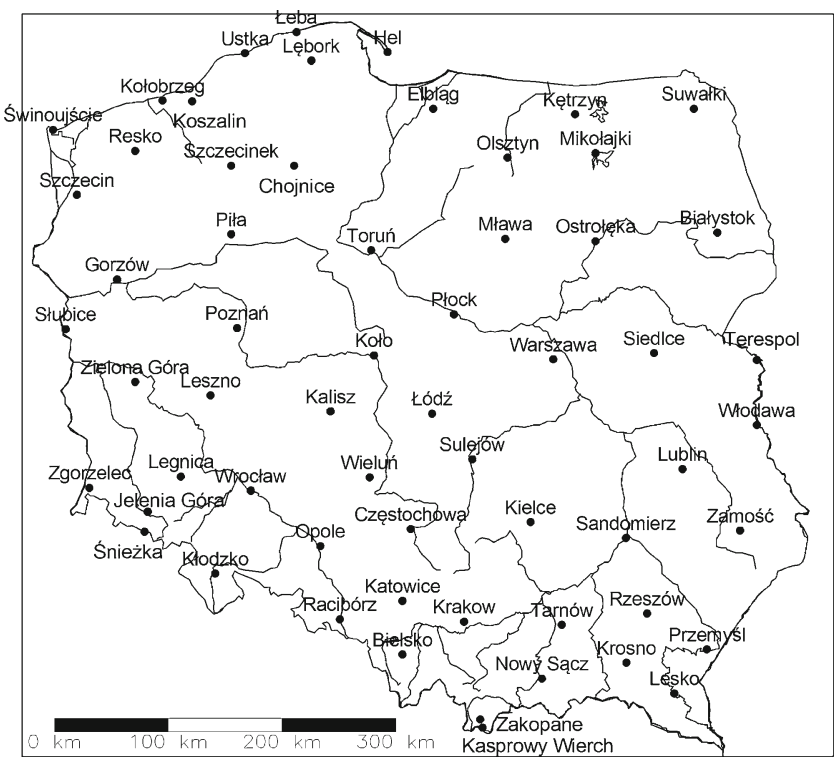

Fig. 1 Locations of meteorological stations used in the study

detailed investigation of ISS relations with both meso- and macroscale indices. Positive values of zonal circulation index evidence a predominance of western advection and a dominating impact of the Atlantic Ocean on climatic conditions in Poland, while negative ones indicate a prevalence advection of continental air masses from the east. High values of the meridional circulation index evidence the intensive advection from the southern sector, while low, negative values indicate major frequency of northern air flow. Positive values of cyclonicity index show a predominance of cyclonic types of atmospheric circulation over anticyclonic ones (Niedźwiedź 1998). Time trends of the $Z_{1}, M_{1}$, and $C$ for Dec-Feb are not statistically significant. However, trends of $Z_{1}$ and $M_{1}$ are little positive throughout the period observed.

Areas of domination influence of zonal or meridional circulation on the snow cover stability in Poland were pointed out by means of the simple correlation coefficient $(r)$. A total influence of atmospheric circulation (expressed by two or three indices) on the ISS was investigated by using two different methods depending on correlation level within each group of atmospheric indices (Stanisz 2007). The time series of all mesoscale indices $\left(Z_{1}, M_{1}, C\right)$ appeared to be not significantly correlated with one another at the level of 0.05 . So, there was no obstacle to use the regression analysis for investigating the atmospheric circulation influence on the snow cover stability. For each meteorological station, a multiple regression equation was created including one to three independent variables related to the circulation. Each equation consists of only statistically significant variable(s). The multiple correlation coefficient and determination coefficient adjusted for the number of freedom degrees were counted. It enabled an estimation of the simultaneous influence of the zonal and meridional circulation and the cyclonicity index on the snow cover stability during winter season in Poland.

The time series of macroscale indices $\left(Z_{2}, M_{2}\right)$ are significantly correlated with one another at the level of $0.05(r=-0.57)$. In such a case a method of principal component analysis is reasonable for investigating the atmospheric circulation influence on the ISS. New series describing atmospheric circulation were created for the first and the second principal component (respectively PC1 and PC2). The relationship of snow cover stability to these series was investigated for the area of Poland. The time trend of the $Z_{2}$ series for Dec-Feb is positive, statistically significant at the 0.05 level, while the trend of $M_{2}$ series (Dec-Feb) is not significant throughout the period observed.

The results of investigation of the ISS relation to the atmospheric circulation obtained by using (1) the multiple regression and by (2) the principal component analysis were compared.

\section{Results}

1. Variability of the snow cover stability index

The PC1 for the ISS below $500 \mathrm{~m}$ above the sea level explains $71 \%$ variation of that index. The long-term run of the standardized values of PC1 multiplied by -1 is very similar to the course of the ISS values averaged for nonmountainous areas of Poland (Fig. 2a). The trend of the series is negative, statistically significant at the 0.05 level. The 5-year average run shows clearly periods of high (1960-1970 and 1975-1985) and low (before 1960, 1970 1975 , and after 1986) values occurring alternately in the second half of the twentieth century. The highest values (above 2) were calculated for winters 1969/1970 and 1986/ 1987 and the lowest one-for winter season 1974/1975. The both PC1 and PC2 for the ISS below $500 \mathrm{~m}$ above the sea level explain $77 \%$ variation of that index. The course of standardized values of PC2 does not reveal a statistically significant change in the analyzed period (Fig. 2b).

The long-term variability of ISS in the mountains is distinctly different from the described above and also is not similar for different mountain ranges (Fig. 3). There is no statistically significant trend in ISS run at the Kasprowy Wierch (West Carpathians, Tatra-mountains; Fig. 3a). Alternately occurring periods of high (before 1960, 1970-1980, and after 1990) and low (1960-1970 and 1980-1990) values did not appear at the same time as in non-mountainous areas. During the analyzed period the ISS at the Kasprowy Wierch summit was not lower than $60 \%(61 \%$ in winter season 1985/1986) and not higher than $95 \%$ (in winter 1954/1955). The trend of ISS at the Śnieżka summit 


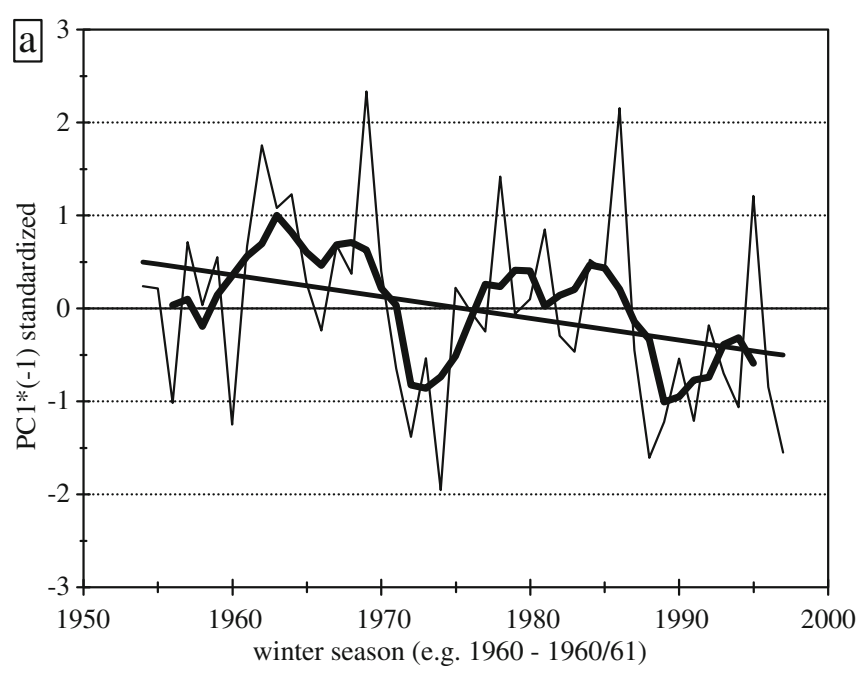

Fig. 2 Variability of standardized values of a PC1*(-1) and b PC2* $(-1)$ for the snow cover stability index in the areas of Poland below 500 ma.s.l. (1954/1955-1997/1998). The trend line and 5-year moving

(Sudeten) is positive (ca. +2 percent points per 10 years) with statistical significance close to the 0.05 (Fig. 3b). In three winter seasons $(1974 / 1975,1991 / 1992,1992 / 1993)$ the real and potential snow cover duration were equal, i.e., ISS was $100 \%$.

2. Influence of the atmospheric circulation on the snow cover stability

The initial investigation results of the influence of the atmospheric circulation on the snow cover stability show in general, the division of Poland area, into two parts: (1) southern part where the meridional circulation influences the ISS stronger than the zonal one (i.e., the absolute value of simple correlation coefficient is higher for the correlation

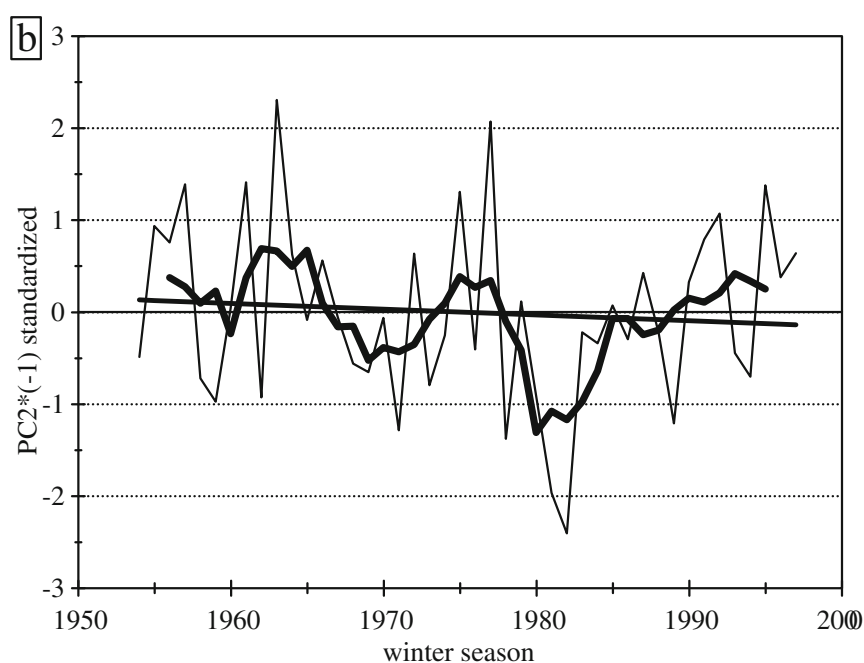

average line (thick) were added. The trend is statistically significant in (a) and not significant in (b) at the 0.05 level

with $M_{1}$ than that one with $Z_{1}$ ), (2) remaining part of the country (except for the higher parts of the mountains and some areas in northern Poland), where the zonal circulation influences the ISS stronger than the meridional one (i.e., absolute value of simple correlation coefficient is higher for the correlation with $Z_{1}$ than that one with $M_{1}$; Fig. 4). For both $Z_{1}$ and $M_{1}$ indices the dependence is inversely proportional in all measure points. The intensive western advection from over the Atlantic Ocean (positive $Z_{1}$ ) usually brings warming and melting the snow cover even in the middle of the winter season in the majority of Poland area. The domination of meridional circulation in southern Poland is strongly connected to the intensification of the southern advection by the foehn effect. In case of the influence on
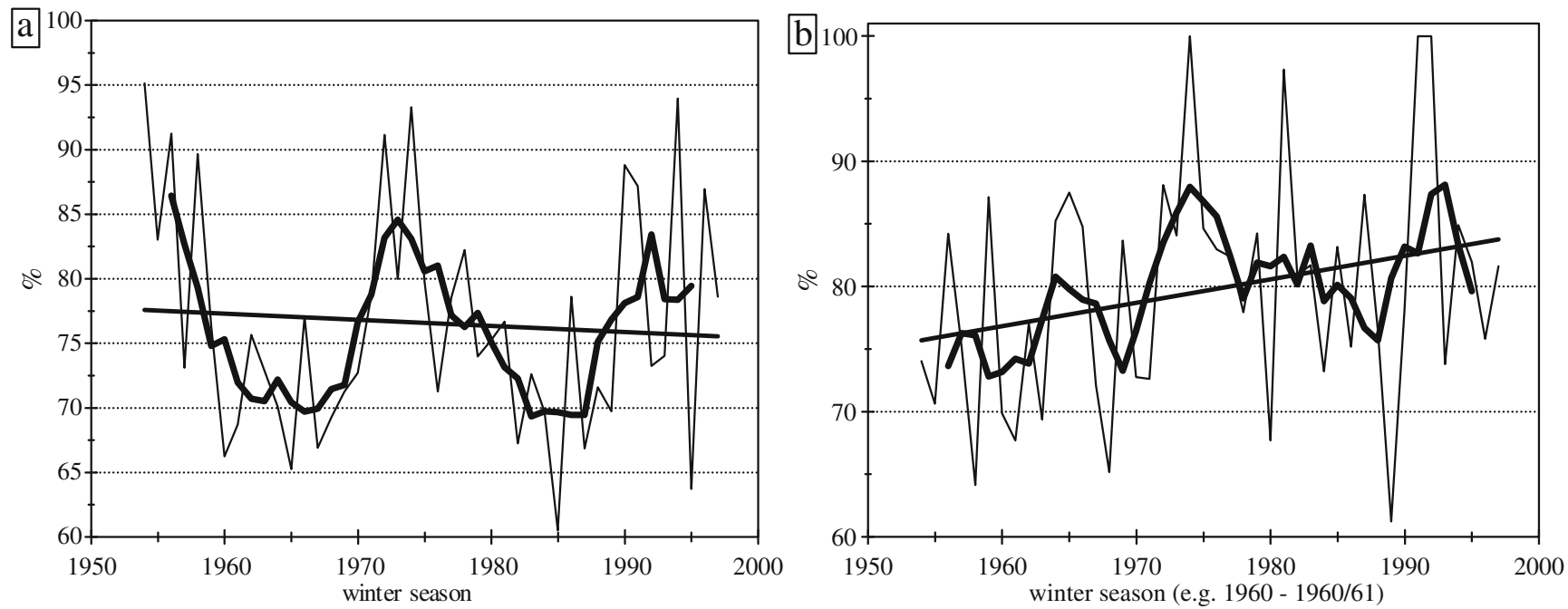

Fig. 3 Variability of snow cover stability index (\%) in 1954/1955-1997/1998 at the summits of a Kasprowy Wierch (1,991 ma.s.1.) and b Śnieżka (1,603 ma.s.1.). The trend line and 5-year moving average line (thick) were added. The trends are not statistically significant 
the ISS it is especially good clear: the area of domination of the meridional circulation is quite large and the foehn effect is visible up to $200-250 \mathrm{~km}$ from the main mountains ridge. In the higher parts of the Sudeten and Tatra mountains no statistically significant influence of circulation atmosphere on the ISS was revealed.

The majority of Poland area the ISS is under the statistically significant total impact of both $Z_{1}$ and $M_{1}$ indices (Fig. 5). However, in some areas in the northern and eastern Poland $Z_{1}$ index is the only one influencing the ISS, while in some areas in the southern Poland (especially in the mountains) $M_{1}$ index is the only one influencing the ISS. For the eastern part of the Carpathian foothills and for some areas of Baltic coast the multiple regression equations consist of three statistically significant components for all atmospheric circulation indices $\left(Z_{1}, M_{1}\right.$, and $\left.C\right)$. The cyclonicity affects also significantly the ISS in the lower part of the western Carpathians and in northeastern Poland. All multiple regression components for $Z_{1}$ and $M_{1}$ indices are of the negative sign, while for $\mathrm{C}$ index, positive in the northern part of Poland and negative in southeastern Poland. The explanation of the latter seems to be quite easy. If a low-pressure center is located over the central Poland, the northern part of the country is under the influence of relatively cold air from northeast, so the snow cover remains there and the ISS grows (i.e., the correlation is directly proportional), while the south Poland is under the influence of relatively warm and wet air from west or southwest, so the snow cover disappears and the ISS drops (i.e., the correlation is inversely proportional). And vice versa: if a high-pressure center is

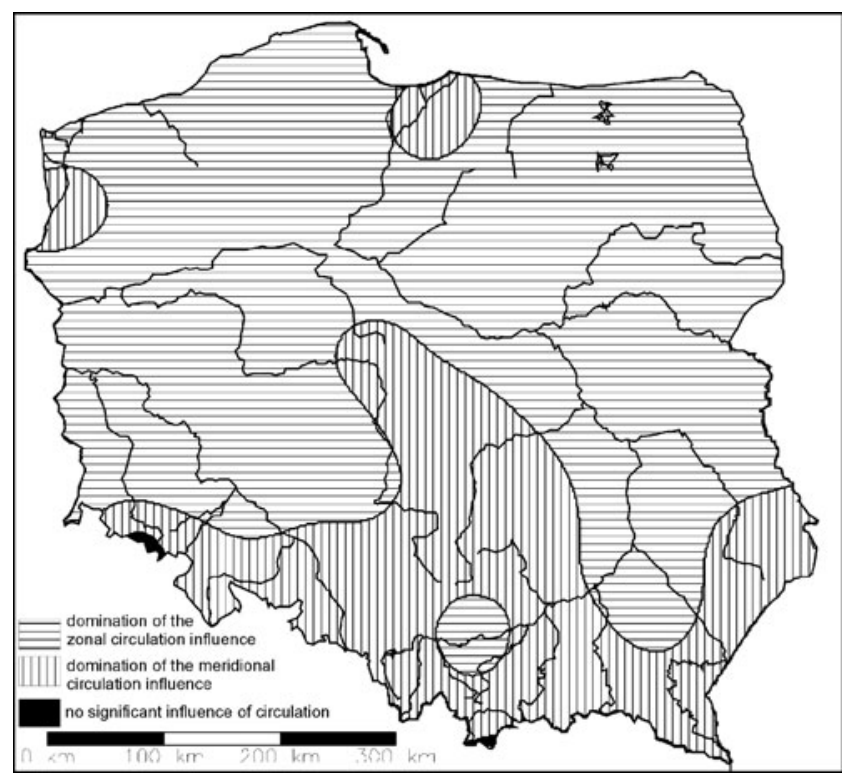

Fig. 4 Areas of domination influence of zonal or meridional circulation (Dec-Feb) on the stability of snow cover (on the ground of simple correlation coefficients for ISS $-Z_{1}$ and ISS $-M_{1}$ ) located over the central Poland, the northern part of the country is under the influence of relatively warm and wet air from southwest, so the snow cover disappears there and the ISS drops, while the south Poland is under the influence of relatively cold air from northeast, so the snow cover remains there and the ISS grows. The negative correlations between the ISS and $C$ index in southeastern Poland are also the results of low-pressure systems located over Germany and western Poland. In such baric situations the advection from southwest reaches that region causing a weak foehn effect and snowmelt.

In areas where the variability of the ISS is described by only one circulation index the values of determination coefficient are the lowest (with the maximum up to $30 \%$; Fig. 5). Changes of two or three indices describe 30-50\% of the ISS variability in Poland. The explanation of the ISS is, in general, larger and larger towards the northwest of the country exceeding $50 \%$ in the Szczecińska Lowland. The $C$ index does not affect significantly the increasing of the determination coefficient; in some areas of its influence (e.g., in northeast and southeast of Poland) the coefficient values are still on a low level.

The PC1 explains $79 \%$ variation of both $Z_{2}$ and $M_{2}$ circulation indices. Values of its matrix covariance vector are 0.794 for $Z_{2}$ and -0.608 for $M_{2}$. So, PC1 stands for the dominant western and northern inflow. The correlation coefficient between a new series created on the base on PC1 vector values and the ISS is not statistically significant in the mountains, foothills, and in some upland areas (southern Poland; Fig. 6a). These areas are mostly regions of the influence of mesoscale southern circulation (see Fig. 4). In the rest of the country the connections are significant but not very strict. The strength of dependency increases in general from southern to northern and northeastern Poland. The highest value of the coefficient are observed in the northeast of Poland ( $r$ up to 0.69 in Suwałki) and in lake district of Pomorze, i.e., mostly in areas of the undivided influence of the zonal circulation described by the index $Z_{1}$ (see Fig. 5).

Values of matrix covariance vector for PC2 counted for both $Z_{2}$ and $M_{2}$ circulation indices are 0.608 for $Z_{2}$ and 0.794 for $M_{2}$. So, PC2 stands for the dominant western and southern inflow. In most area of Poland the correlation coefficient between a new series created on the base on PC2 vector values and the ISS is statistically significant (Fig. 6b). The strength of dependency increases in general from northern to southern Poland. The highest value of the coefficient are observed in foothills areas $(r=-0.68$ in Nowy Sacz, -0.62 in Racibórz and Tarnów) where the southern mesoscale circulation connected to the foehn effect dominates over the western one (see Fig. 4). In the highest parts of the mountains and in lake district of Pomorze the analyzed dependency is not statistically significant. 


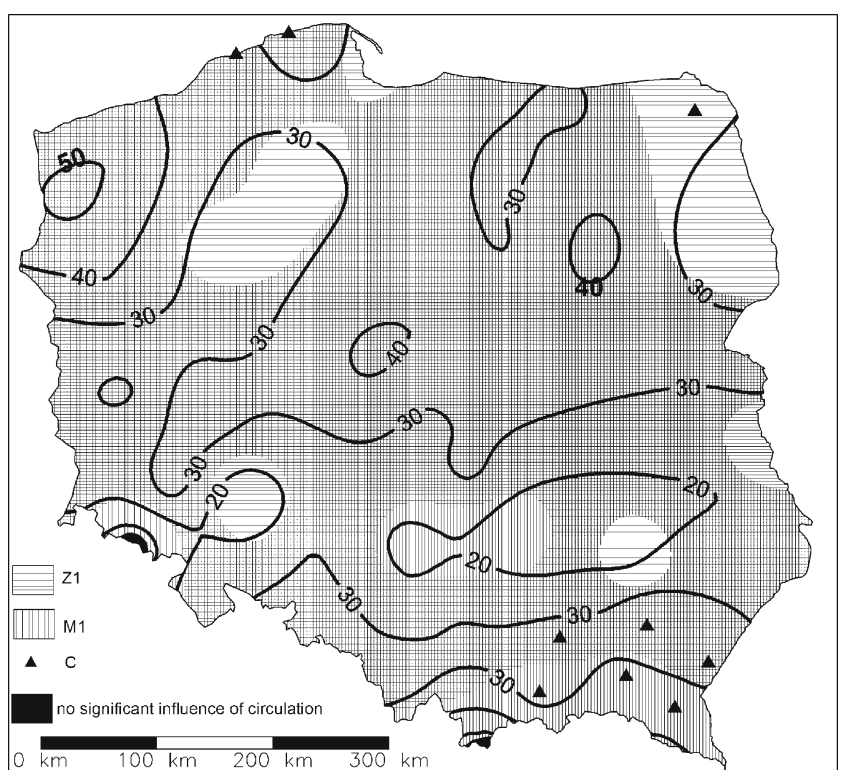

Fig. 5 Areas of a significant influence of zonal $\left(Z_{l}\right)$ and meridional $\left(M_{I}\right)$ circulation and the cyclonicity $(C$; Dec-Feb) on the stability of snow cover (on the base of multiple regression analysis). Isolines of determination coefficient (in \%) adjusted for the number of freedom degrees are shown

So, the macroscale circulation explains up to $46 \%$ of the ISS in Poland (determination coefficient corrected for the number of freedom degrees).

\section{Discussion and conclusion}

The principal results of the study are as follows:

- Both PC1 and PC2 for the index of snow cover stability below $500 \mathrm{~m}$ above the sea level explain $77 \%$ variation of that index. The trend is negative for standardized values of $\mathrm{PC} 1 *(-1)$, while not significant for $\mathrm{PC} 2 *$ $(-1)$; in the summit parts of Sudety the snow cover stability was increasing during the second half of the twentieth century.

- Alternately occurring periods of high and low values of the index of snow cover stability did not appear simultaneously in mountainous and nonmountainous areas.

- In the majority of Poland area both zonal and meridional components of the atmospheric circulation influence the snow cover stability; however, in the south (except for the highest part of the mountains) the meridional air flow reveals the stronger impact, mostly due to the intensification of the southern advection by the foehn effect. In the remaining part of the country the zonal air flow has the stronger effect, mostly as a result of the warming influence of the Atlantic Ocean.

- In some areas of southern and northern Poland the snow cover stability depends also significantly on the cyclonicity index.

- Changes of two or three indices describing atmospheric circulation explain up to $50 \%$ of the snow cover stability in Poland.

- The mesoscale circulation reveals the strongest impact on the ISS in northwestern Poland, while the macroscale one-in northern and northeastern part of the country during the western and northern air flow and in southern and southwestern Poland during the southern, southwestern, and western advection.

- In the highest parts of mountain areas the snow cover stability is very high and due to long time of accumulation and disappearing of snow does not depend directly on circulation variability.

Changes of snow cover stability in Poland are more or less in agreement with these high-latitude and highelevation areas in the Northern Hemisphere: the lastobserved snow cover in spring shifted in these areas earlier by $3-5$ days/decade and the duration of the snow-free period
Fig. 6 Correlation coefficient between PC1 (a), PC2 (b) for both $Z_{2}$ and $M_{2}$ indices (DecFeb) and the stability of snow cover in Poland. Diagonal hachure indicates areas of insignificant influence of atmospheric circulation
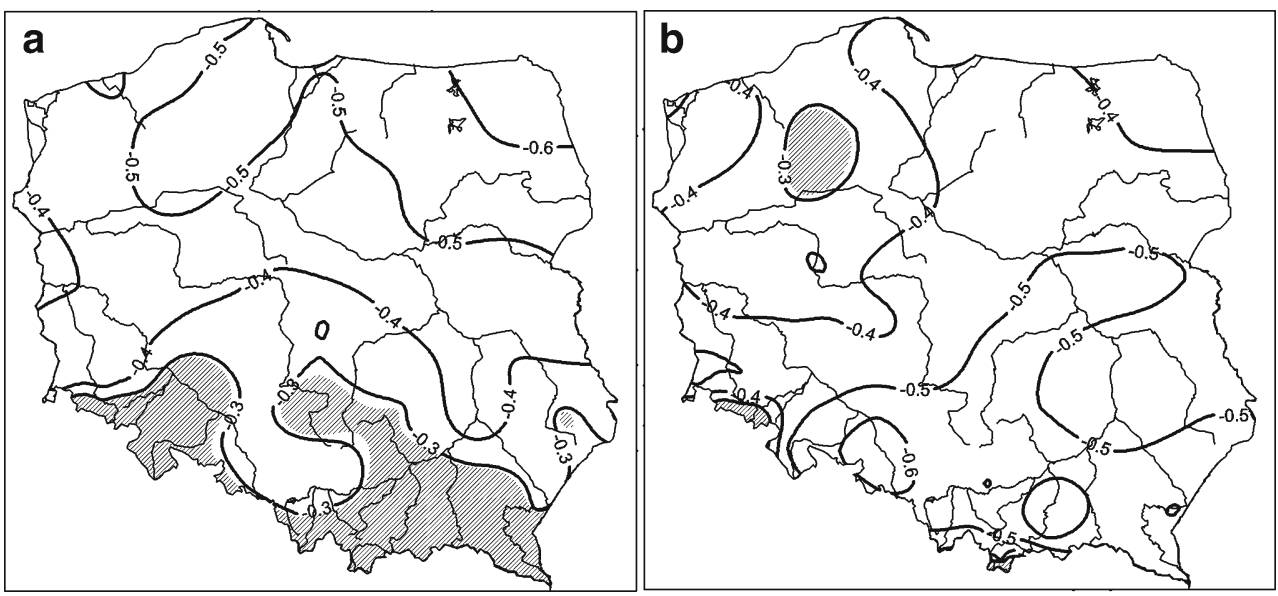
increased by 5-6 days/decade in 1972-2000, primarily due to earlier snow cover disappearance in spring (Dye 2002).

The diminishing stability of snow cover in Poland corresponds with an increasing intensity of the advection from the western sector in winter in the second half of the twentieth century in Europe, especially after 1970 or 1980 (Hurrell 1995; Niedźwiedź 2000; Ustrnul 2007). Henderson and Leathers (2010) confirm the strong associations between large (small) snow cover seasons and the negative (positive) phase of the North Atlantic Oscillation.

In southern Poland, the meridional circulation, especially the advection from the south, is an additional factor intensifying the negative trend of the snow cover stability. The time tendency of the stability of snow cover is, in fact, the strongest (statistically significant) in some measure points of the southern half of Poland (Falarz 2010). The positive time tendency of the mesoscale meridional circulation index is not significant, but, due to the particular sensitivity of snow to the foehn effect, it seems to have a strong impact on snow cover stability. Advection from southwest shows often features of foehn as well; it is observed in southern Poland in about $12 \%$ days in December and January (Niedźwiedź 2003). A similar influence is observed over east European Plain, where the warm air associated with southwesterly winds and the adiabatic heating of descending air are primarily responsible for the rapid snowmelt in March and April (Ueda et al. 2003). The foehn effect influence on the snow cover stability in Poland appears to be much stronger and visible on far larger surface than this one on snow cover duration and snow cover depth analyzed before (Falarz 2007a).

The directly proportional relations of the snow cover stability - atmospheric cyclonicity in northern Poland is the result of heavy frontal snowfalls connected to lowpressure systems over the Baltic Sea (Bednorz 2011). On the other hand, the midlatitude cyclones can cause midwinter snowmelt episodes due to elevated wind speeds and stronger temperature and humidity gradients significantly increased the transfers of sensible and latent heat between the snow surface and the atmosphere (Grundstein and Leathers 1998). That seems to be the explanation of negative snow cover stability - cyclonicity relations in southeastern Poland.

Changes of indices describing atmospheric circulation explain hardly up to $50 \%$ of variations in snow cover stability during the second half of twentieth century. For improving the results, the simultaneous action of atmospheric circulation, air temperature, and snow precipitation on the ISS should be taken into account in further investigation.

Acknowledgments I would like to thank Jean-Michel Fallot and the second anonymous reviewer for very helpful comments and critiques, which improved the manuscript.

Open Access This article is distributed under the terms of the Creative Commons Attribution License which permits any use, distribution, and reproduction in any medium, provided the original author(s) and the source are credited.

\section{References}

Bao Z, Kelly R, Wu R (2011) Variability of regional snow cover in spring over western Canada and its relationship to temperature and circulation anomalies. Int J Climatol 31:1280-1294

Bednorz E (2002) Snow cover in western Poland and macro-scale circulation conditions. Int J Climatol 22:533-541

Bednorz E (2009) Wpływ sytuacji barycznych na występowanie pokrywy śnieżnej na obszarach nizinnych środkowej Europy. Wyd Nauk UAM, Poznań

Bednorz E (2011) Synoptic conditions of the occurrence of snow cover in central European lowlands. Int J Climatol 31:1108-1118

Brown RD (2000) Northern Hemisphere snow cover variability and change, 1915-97. J Climate 13:2339-2355

Brown RD, Mote PW (2009) The response of Northern Hemisphere snow cover to a changing climate. J Climate 22:2124-2145

Clark MP, Serreze MC, Robinson DA (1999) Atmospheric controls on Eurasian snow extent. Int J Climatol 19:27-40

Dye DG (2002) Variability and trends in the annual snow-cover cycle in Northern Hemisphere land areas, 1972-2000. Hydrol Processes 16:3065-3077

Falarz M (2002) Wieloletnia zmienność pokrywy śnieżnej w Polsce na tle zmian cyrkulacyjnych, termicznych i opadowych. Dissertation, Jagiellonian University

Falarz M (2004) Variability and trends in the duration and depth of snow cover in Poland in the 20th century. Int J Climatol 24:1713-1727

Falarz M (2007a) Snow cover variability in Poland in relation to the macro- and mesoscale atmospheric circulation in the 20th century. Int J Climatol 27:2069-2081

Falarz M (2007b) Potencjalny okres występowania pokrywy śnieżnej w Polsce i jego zmiany w XX wieku. In: Piotrowicz K, Twardosz $\mathrm{R}$ (eds) Wahania klimatu $\mathrm{w}$ różnych skalach przestrzennych $\mathrm{i}$ czasowych. IGiGP UJ, Kraków, pp 205-213

Falarz M (2010) Współczynnik trwałości pokrywy śnieżnej w Polsce rozkład przestrzenny, ekstrema, zmiany wieloletnie. In: Bednorz E (ed) Klimat Polski na tle klimatu Europy-warunki termiczne i opadowe. Bogucki Wydawnictwo Naukowe, Poznań, pp 169-180

Groisman PY, Karl TR, Knight RW, Stenchikov GL (1994) Changes of snow cover, temperature and the radiative heat balance over the Northern Hemisphere. J Climate 7:1633-1656

Grundstein AJ, Leathers DJ (1998) A case study of the synoptic patterns influencing midwinter snowmelt across the northern Great Plains. Hydrol Processes 12:2293-2305

Gutzler DS, Rosen RD (1992) Interannual variability of wintertime snow cover across the Nothern Hemisphere. J Climate 5:14411447

Henderson GR, Leathers DJ (2010) European snow cover extent variability and associations with atmospheric forcings. Int J Climatol 30:1440-1451

Hurrell JW (1995) Decadal trends in the North Atlantic Oscillation. Regional temperature and precipitation. Science 269:676-679

Leathers DJ, Mote TL, Grundstein AJ, Robinson DA, Felter K, Conrad K, Sedywitz L (2002) Associations between continental-scale snow cover anomalies and air mass frequencies across eastern North America. Int J Climatol 22:1473-1494

Leśniak B (1973) O niektórych charakterystykach pokrywy śnieżnej w województwie krakowskim. Zesz Nauk UJ Prace Geograficzne 32:119-128

Leśniak B (1981) Współczynnik trwałości pokrywy śnieżnej na obszarze dorzecza górnej Wisły. Folia Geogr Ser Geogr-physica 14:89-102 
Niedźwiedź T (1998) Variability of atmospheric circulation indices above the Western Carpathians. 2nd European Conference on Applied Climatology, Vol 19, Öster. Beiträge zu Meteor und Geophysik, Central Inst. for Meteor. and Geodynamics, Vienna (CD-ROM)

Niedźwiedź T (2000) Variability of the atmospheric circulation above Central Europe in the light of selected indices. Zesz Nauk UJ Pr Geogr 107:379-389

Niedźwiedź T (2003) Variability of atmospheric circulation in southern Poland in the 20th century. In: Pyka JL, Dubicka M, Szczepankiewicz-Szmyrka A, Sobik M, Błaś M (eds) Man and climate in the 20th century. Studia Geogr, Acta Universitatis Wratislaviensis, Wrocław, pp 230-240

Niedźwiedź T (2011) Kalendarz typów cyrkulacji atmosfery dla Polski południowej-zbiór komputerowy (Calendar of Circulation Types for teritory of Southern Poland-computer file). http:// klimat.wnoz.us.edu.pl Accessed 30 March 2011

Osuchowska-Klein B (1975) Prognostyczne aspekty cyrkulacji atmosferycznej nad Polską. Prace IMGW 7:4-51

Osuchowska-Klein B, Pawłowska D (2000) Kalendarz typów cyrkulacji dla Polski, 1901-1998. (computer file)
Rodell MP, Houser R (2004) Updating a land surface model with MODIS-derived snow cover. J Hydrometeor 5:064-1075

Saito K, Yasunari T, Cohen J (2004) Changes in the sub-decadal covariability between Northern Hemisphere snow cover and the general circulation of the atmosphere. Int J Climatol 24:3-44

Stanisz A (2007) Przystępny kurs statystyki z zastosowaniem Statistica PL na przykładach z medycyny. Analizy wielowymiarowe, Statsoft

Strack JE, Pielke RA, Adegoke J (2003) Sensitivity of modelgenerated daytime surface heat fluxes over snow to land-cover changes. J Hydrometeor 4:4-42

Ueda H, Shinoda M, Kamahori H (2003) Spring northward retreat of Eurasian snow cover relevant to seasonal and interannual variations of atmospheric circulation. Int J Climatol 23:615629

Ustrnul Z (2007) Warunki cyrkulacyjne. In: Matuszko D (ed) Klimat Krakowa w XX wieku. IGiGP UJ, Kraków, pp 21-40

Walland DJ, Simmonds J (1997) Modelled atmospheric response to changes in Northern Hemisphere snow cover. Clim Dynamics $13: 5-34$ 